\title{
UNAS NOTAS SOBRE LA CRUELDAD FEMENINA EN LOS LIBROS DE CABALLERÍAS DE FELICIANO DE SILVA (EL CASO DE SIDONIA)
}

\author{
Emilio José SALes Dasí \\ IES. Abastos (València) \\ José Manuel Lucía Megías \\ Universidad Complutense Madrid
}

Aunque los libros de caballerías se planteen como un imaginario panegírico del universo masculino y utilicen como reclamo editorial, desde sus mismas portadas, la imagen protagonística del varón, deberá subrayarse que la presencia femenina en estas obras es cada vez más significativa y que los autores tienden a diversificar su papel actancial, a través de múltiples plasmaciones tipológicas que apuntan más allá de la imagen prototípica de la princesa hermosa, pero más o menos pasiva, cuya biografía surge en función del propio desarrollo personal del héroe caballeresco. Tomando como punto de partida una tipología de las mujeres que aparecen en los folios del Amadís de Gaula ${ }^{1}$, su cotejo conjunto con las numerosísimas aportaciones realizadas en libros posteriores vendría a demostrar que la mayoría de los autores del género caballeresco están empeñados en utilizar a la mujer no sólo como instrumento enriquecedor de sus tramas, a partir de sus diversos roles, sino también como vehículo idóneo para involucrar al sexo femenino en la lectura de sus fábulas ${ }^{2}$. Resulta evidente, claro está, no todas las mujeres del XVI

\footnotetext{
${ }^{1}$ Tarea esta iniciada por Marta Haro Cortés, en «La mujer en la aventura caballeresca: dueñas y doncellas en el Amadís de Gaula», Literatura de caballerías y orígenes de la novela, ed. de Rafael Beltrán Llavador, València, Universitat, 1998, pp. 181-217.

${ }^{2}$ En opinión de M. ${ }^{a}$ Carmen Marín Pina, el teórico público femenino de la época le concedería a los libros de caballerías una importancia similar a la de las ficciones sentimentales y los relatos pastoriles: «En definitiva, los libros de caballerías tuvieron tanto éxito entre el público femenino como las otras ficciones del momento, ficciones a las que, no hay que olvidar, ellos mismos en ocasiones dieron cabida en sus páginas» («La mujer y los libros de caballerías. Notas para el estudio de la recepción del género caballeresco entre el público femenino», Revista de Literatura Medieval, 3 (1991), pp. 129-148, p.148). Podían estar interesadas en la idílica imagen que se ofrecía de las deslumbrantes amadas y compañeras del héroe, incluso también en la intensidad de las anécdotas militares. En todo caso, el retrato que se ofrece de las mujeres en el conjunto del corpus editorial caballeresco es vastísimo y diversificado. Tanto
} 
tendrían acceso a tales obras, ni podrían engrosar las filas de sus adeptos seguidores. Sin embargo, por debajo de los hostiles anatemas con que algunos humanistas, enemigos de la ficción caballeresca, denunciaban la peligrosidad moral de estas ficciones, intentando disuadir a las mujeres de un hipotético desliz lector, para que pudieran cumplir convenientemente con el papel que les había otorgado su sociedad ${ }^{3}$, puede presumirse la progresiva implicación de buenas damas y doncellas en un ámbito literario que igual conocerían individualmente como a través de una lectura en voz alta.

Si las circunstancias específicas de aquel tiempo no les permitían a las hijas, madres o esposas, poseer un grado de libertad equiparable al que disfrutaban las ficticias criaturas de los textos caballerescos, tenían motivos sobrados para admirarse o encandilarse con las hazañas y amores de intrépidos paladines, pero, asimismo, de idílicas heroínas con las que soñar en los rincones de la imaginación. Tal vez, una estadística aproximada de las mujeres que sabían leer en aquella época o podían acceder a estos relatos sería de gran utilidad para aseverar que, además de Santa Teresa de Jesús, hubo otras lectoras que compartieron esa misma afición y a las que tenían en mente los propios escritores a la hora de satisfacer determinadas expectativas. Dado que una aproximación estrictamente sociológica tampoco arrojaría la suficiente luz, intentemos analizar desde el marco autónomo de algunas obras caballerescas un aspecto concreto de la presencia femenina: su hiperbólica crueldad en algunas ocasiones.

Dígase en primera instancia que, cuando se plantea el tema de la crueldad, lo primero que se nos viene a la cabeza es la figura de la mujer brava, de una dama que ha sufrido alguna pérdida familiar y que responde con un furibundo instinto vengativo, ya sea directamente, ya sea a través de algunos aliados o del recurso al engaño o a procedimientos mágicos. Mujer cuyo esposo muerto

en los tipos inventados como en la amplitud de roles actanciales que se le atribuyen a las féminas.

${ }^{3}$ Bastará recordar, a título ilustrativo, que intelectuales como Juan Luis Vives condenan en varios lugares de sus obras, entre otras manifestaciones literarias, a los libros de caballerías: «la voluptuosidad impregna la mayor parte de las obras de los poetas; las fábulas milesias como "El asno de oro" de Apuleyo; casi todas las de Luciano; las que en elevado número se han escrito en lenguas vernáculas, como Tristan, Lancelot, Ogeres, Amadises, Arturos y otras semejantes. Todos estos libros fueron escritos por hombres ociosos, con mucho papel a su alcance, ignorantes en temas de mayor altura» (De officio mariti, 1529, cap. V, ed. Joan Lluís Vives, digital, Biblioteca Valencia Digital [http://bv.gva.es]). Varias de estas críticas obedecen a su deseo de preservar su imagen de la mujer ideal, la misma que encontrará su razón de ser en el matrimonio y cuya hipotética instrucción lectora debe estar controlada por otros varones. Sobre estas ideas y otras similares que esgrimieron autores peninsulares renacentistas, siguiendo la línea de Erasmo en su Encomium matrimonii (1526), remitimos a los comentarios vertidos por M. ${ }^{a}$ Isabel Romero Tabares, «Modelos de mujeres en los libros de caballerías hispánicos. El Rosián de Castilla», en «Fechos antiguos que los cavalleros en armas passaron». Estudios sobre la ficción caballeresca, ed. de J. Acebrón, Lleida, Edicions Univ. Lleida, 2001, pp. 191-215. 
en alguna batalla o justa, madre cuyo hijo ha sufrido idéntica suerte, $y$, por extensión, hija que ha perdido a su padre o a su hermano, se ubican desde un principio en el bando de los personajes antagónicos, en tanto que consideran al héroe como responsable de su infortunio, y asumen, desde entonces, una actitud enemiga similar a la de los desalmados gigantes, caballeros soberbios o guerreros paganos. Como una nueva variante del tipo de la mujer-dueña brava y vengativa, se revela en algunos casos interesante aquel de la mujer que manifiesta una inimaginable y atroz conducta como respuesta contundente a una humillación sufrida (por ejemplo, una violación) o a la imposibilidad de consumar sus aspiraciones amorosas, muchas veces satinadas por un evidente sentimiento de lascivia. Estas posibilidades narrativas, aparte de otras ya enunciadas en un trabajo anterior ${ }^{4}$, sorprenden a los lectores y lectoras por el uso y abuso de una extrema violencia. Contrástense, por ejemplo, las siguientes situaciones.

En el Floriseo (1516) sabremos de las perversas maquinaciones de la sabia Urbicaria, a través de la relación que le hace al caballero protagonista la esposa del difunto caballero Anteno. Urbicaria es responsable de los males directos que afectan a esta dueña y por eso se exige de una justa venganza para su conducta desordenada. Como la propia viuda apenada relatará, Anteno tuvo amores con Urbicaria. Sin embargo, sus relaciones amorosas fueron cambiando con el tiempo:

Dende [su castillo] hizo llamar a mi marido, el cual ya la desamava, ansí por su mal parecer como porque no podía sofrir sus encantamientos e porque no avía hijos d'ella. E como en este tiempo mi marido me tomasse por muger, olvidó a esta traidora de todo punto. E no sólo esto, pero nunca nombró su nombre ni quiso recebir carta suya, aunque muchas le embió, todo lo cual fue causa que esta hechizera tomasse furia mortal con desseo de vengança de mi señor. Y como ella viesse que de sus cartas se hazía poca pro, acordó venir en persona a mi casa. E como mi marido no faltasse punto de buena criança, recibiola como convenía, e yo hízele el mejor recibimiento que pude. Y el color de su venida fue dezir que iva a Atenas, e ansí estovo en mi casa descansando dos días para me dar a mí trabajo toda mi vida.

Y al cabo d'estos días, saliendo mi marido a la despedir sin llevar cuidado de sí, aviéndose alexado media legua de mi casa hizo esta traidora a sus criados que matassen a mi marido. E ansí fue que ella por sus manos le cortó la cabeça e la lleva como vistes (1. ${ }^{\mathrm{a}}$, LVIII, 107$)^{5}$.

\footnotetext{
${ }^{4}$ Emilio J. Sales Dasí, «La dueña traidora: venganzas y secuestros en las continuaciones del Amadís de Gaula», Medievalia, 32/33 (2001), pp. 24-36.

${ }^{5}$ Citamos por la edición de Javier Guijarro Ceballos, Alcalá de Henares, Centro de Estudios Cervantinos, 2003.
} 
El Floriseo, texto en el que su autor, Fernando Bernal, diversifica el universo actancial del género caballeresco, incorporando un largo inventario de «navegantes, militares de baja extracción social, bufones de corte, bastardos, homosexuales, adúlteras o prostitutas $\rangle^{6}$, destaca la crueldad de una mujer egoísta que no acepta un rechazo amoroso, pasando por encima de cualquier convención social para satisfacer su enojo. La suya es una brutalidad condenable que exigirá de la intervención del héroe.

También en el Amadis de Grecia (1530) de Feliciano de Silva se cruzan las figuras de los heroicos caballeros protagonistas y la de otra mujer cruel. Pese a ello, el episodio que traemos a colación varía en sus esquemas compositivos con respecto al del Floriseo. Mientras en aquella obra Urbicaria se define como airada infractora del status quo, aquí nos toparemos con la desproporcionada reacción de una joven que pasa a ser víctima de una terrible tragedia familiar y personal. Hablamos de la princesa Malfadea de la Cíclada Mayor. La historia de esta jayana es por sí sola significativa del proceder novelesco de su creador, puesto que a partir de su peripecia Feliciano de Silva «acumula, modifica, elimina y crea nuevos motivos que pasan a integrar el corpus caballeresco ${ }^{7}$. Con ser importante este aspecto, sobre el que volvemos más adelante, nos interesa detenernos, sin embargo, en uno de los momentos en que cobran forma los instintos más primarios de una joven que ha sido cortejada por el gigante Mascarón y que, después de rechazarlo, sufre una gravísima agresión, ya que su pretendiente mata a sus padres y la viola. Desposeída del reino que le pertenecía en herencia, manchada su honra y sin familiares directos a los que recurrir, esta princesa jayana actúa como mujer cuitada que demanda auxilio. En principio recaba la ayuda del viejo Amadís de Gaula, aunque, finalmente, será también el concurso del Caballero de la Ardiente Espada, sobrenombre de Amadís de Grecia, el que se revele decisivo para castigar la infracción cometida por Mascarón. Es entonces, en el instante en que los paladines consuman su empresa, seccionando la cabeza del perverso gigante, cuando Malfadea sacia su furia y su dolor con unos gestos que traducen una crueldad inusitada:

\footnotetext{
${ }^{6}$ Javier Guijarro Ceballos, «El Floriseo de Fernando Bernal (1516) y su continuación, el Reimundo de Grecia (1524)», en Edad de Oro, 21 (2002), pp. 205-223, p. 211. El mismo autor desarrolla la idea del talante más realista de la obra, a partir del concurso de personajes que podrían definirse como "marginales" en contraste con los tipos actanciales dominantes en el género, en su libro El "Floriseo" de Fernando Bernal, Mérida, Editora Regional de Extremadura, 1999.

${ }^{7}$ Ana Bueno y Carmen Laspuertas, «Introducción» a su ed. Feliciano de Silva, Amadís de Grecia, Alcalá de Henares, Centro de Estudios Cervantinos, 2004, p. xvi.
} 
La jayana Malfadea, como vio la cabeça de Mascarón qu'el rey cortara, con tanta braveza que no se os podría dezir y con sus uñas y dientes como una leona, en un punto la desfizo, y no se hartava de comerle la carne.

- Agora os digo - dixo el rey- que nunca vi tan leal ni buena donzella como esta, pues le parece que aún no es vengada de la muerte de sus padres (1. $\left.{ }^{\mathrm{a}}, \mathrm{XLII}, 143\right)$.

A través de unos terceros, puesto que carece de habilidades mágicas, frente a lo que es habitual en las dueñas traidoras, Malfadea se ensaña con su violador, ya difunto. Su comportamiento antropofágico asume un carácter hiperbólico, efectista. En su caso, aunque su licitud sea discutible, tal forma de proceder se justifica como una respuesta paralela, por su desmesura, al daño recibido ${ }^{8}$.

Desde luego, a poco se ahonde en la consideración de las prácticas utilizadas por algunas criaturas femeninas para satisfacer su enojo o infortunio, se coincidirá en la nulidad de su atractivo como modelo literario capaz de inspirar conductas paralelas. Y mucho más si tomamos en consideración las prácticas odiosas de algunas malas encantadoras que evidencian su condición idolátrica y casi diabólica con un derramamiento de sangre que salpica a muchas víctimas inocentes. Recuérdese, por ejemplo, cómo actúa en el Policisne de Boecia (1602) de Juan de Silva y de Toledo, último libro de caballerías impreso, la principal adversaria del protagonista:

Viendo Almandroga que el mal de Fidea iva adelante, que cada día se iva secando y menguando su hermosura, no hazía sino traer donzellas y niñas inocentes, y entrava en la sala y, desnudándose todas sus vestiduras, tomava un vazín de oro do sacrificava las niñas delante del ídolo que más devoción tenía. Y después, tomando la sangre, se untava toda, echándola sobre sus blancas canas; y tomando unos incensarios de oro, andava ansí por todos los altares ahumando sus ídolos. Esto hazía de tercer en tercer día, pensando que el mal de Fidea permitían sus dioses por la muerte de Furión. Muchos días hizo esto, que ninguno de sus dioses le hablavan ni respondían a sus preguntas, por lo cual tenía creído ser verdad averse enojado contra ella y por aplacar su ira hazía sus sacrificios más a menudo. Bien fueron muertos por su mano más de diez doncellas y otros tantos niños inocentes que por sus artes trahía a sacrificarlos antes que ninguno le respondiesse, ni el espíritu de la piedra le dixesse la causa (cap. XXXVII) ${ }^{9}$.

\footnotetext{
${ }^{8}$ Tobias Brandenberger mantiene la hipótesis de que la brutal resolución del episodio vendría a ser «otra versión, más horripilante si cabe, de la muerte novelesca del poeta Pere Torroellas que ha violentado discursivamente [en el Grisel y Mirabella de Juan de Flores] a las mujeres en general y es dilacerado a manos de las damas de la corte» («Libros de caballerías y ficción sentimental: el taller de Feliciano de Silva», en Revista de Literatura Medieval, 15/1 (2003), pp. 55-80, p. 68, n. ${ }^{\circ} 29$ ).

${ }^{9}$ Citamos por la edición de 1602, Valladolid, Herederos de Juan Íñiguez de Lequerica.
} 
Al poco de deshacerse de su esposo Furión, quien andaba enamorado de su propia hija Fidea ${ }^{10}$, Almandroga tiene que hacer frente a un duro revés: Fidea ha enfermado de una extraña dolencia. Para curarla, la maga confía en la mediación de sus ídolos y les ofrece sacrificios humanos. Su conducta delata un primitivismo deplorable que viene a destacar su oscuro empaque moral, el de una mujer de la que decía el narrador que, junto a su marido, devoraba a sus rivales. Descrita con hábitos antropofágicos, como idólatra y enemiga de Dios, o como cruel asesina, su dimensión como mujer vengativa es sólo una faceta más de su etopeya que la cualifica como encarnación de las fuerzas del mal. Y por eso mismo, en tanto que sus actos tienden a alterar la estabilidad del orden instituido por la Providencia, su eliminación será justa y sumamente lógica.

Ni que decir tiene que personajes como Almandroga despertarían la inquina de los lectores y potenciales lectoras de las ficciones caballerescas. El sentimiento de complicidad de estas últimas debería surgir, preferiblemente, a través de episodios en los que personajes de su mismo género fueran capaces de conjugar su envidiable apariencia externa con una inusitada habilidad para competir con los varones en su mismo campo de acción. A través de aventuras como aquellas protagonizadas por espléndidas amazonas que, aparte de su exótica belleza, deslumbraban con sus aptitudes para derribar a sus rivales con la lanza o con un diestro manejo de sus espadas, o aquellas en que, como por arte de encantamiento, una frágil princesa podía enfundarse por vez primera una pesada armadura y partir en busca de su amado, manejando con singular suficiencia unas armas en cuyo uso nunca había sido adiestrada. Los atributos caracterizadores de estas virgo bellatrix o doncellas guerreras, celebradas tanto por su aspecto físico, su capacidad para doblegar a afamados caballeros y la libertad de que disfrutaban para desplazarse por cualquier geografía, según les dictase su propia iniciativa ${ }^{11}$, serían, indudablemente, mucho mejor recibidas por el público femenino que aquellas otras mujeres bárbaras y sedientas de sangre. No obstante, algunos autores todavía podían depararnos algunas gratas sorpresas de la mano de su instinto creador.

Llegados a este punto, deberemos detenernos en los ejercicios literarios del mentado Feliciano de Silva, autor que enriqueció la trama caballeresca y sentimental del modelo paradigmático amadisiano con una destreza inigualable.

${ }^{10} \mathrm{El}$ enamoramiento incestuoso del padre de su hija reproduce el famoso episodio que da origen al Endriago del Amadís de Gaula (3. ${ }^{\circ}$, LxxIII), aunque en el Policisne se da un giro total al modelo precedente.

${ }^{11}$ Para un mejor conocimiento de la figura de la virgo bellatrix sigue siendo de obligada consulta el trabajo de M. ${ }^{a}$ Carmen Marín Pina, «La aproximación al tema de la virgo bellatrix en los libros de caballerías españoles», en Criticón, 45 (1989), pp. 81-94. 
A fuerza de experimentar, para afianzar su proyecto literario, sobre la materia heredada, sus continuaciones del Amadís de Gaula aportaron múltiples novedades al seno de la ficción caballeresca ${ }^{12}$, novedades que se forjaban con un carácter diferencial, que revelaban un proceso de gradación hiperbólica o que, sencillamente, introducían admirables apuestas argumentales. Como consecuencia de ello, terminaron diversificándose tanto los esquemas tipológicos masculinos como, de formar paralela, los femeninos. Así hasta llegar a tipos sumamente originales que no es que estuvieran dotados de un profundo psicologismo (noción que era desconocida por sus mismos creadores y que frecuentemente se suele utilizar a posteriori), sino que venían a ilustrar los esfuerzos del autor por llevar a cabo determinadas renovaciones temáticas, con el concurso de una retórica argumental y estructural presidida por el efectismo.

Es en este ámbito particular donde tiene cabida un personaje femenino descrito por su extrema crueldad, a pesar de que esta conducta, por morbosa que se crea, no la ubica en la esfera de los antagonistas del relato, sino que se vincula estrechamente al motivo de los efectos del amor y la necesidad de afrontarlos para preservar la honra. Al fin y al cabo, la dialéctica que unifica el desarrollo narrativo de la Primera y segunda parte del Florisel de Niquea ${ }^{13}$ (1532) (Amadis $X$ ), obra en la que reina Sidonia, señora de la Ínsula de Guindaya, aparece hacia el final, pero con una participación a todas luces significativa. Especialmente, porque su existencia contribuye a retomar otra aportación ensayada en varias ocasiones por Feliciano de Silva. Esto es. Sidonia se nos presentará como dama encumbrada, de extraordinaria hermosura, terriblemente cruel, como veremos, y señora de un espacio que va a convertirse en centro geográfico en la Tercera parte del Florisel (1535) (Amadís XI). Todo un aspecto de capital importancia el de la existencia de unas cortes femeninas que puedan rivalizar en calidad con otras cortes gobernadas por hombres y que Silva explota con la intención, posiblemente, de satisfacer también las expectativas de un público femenino.

\footnotetext{
${ }^{12}$ En su intento de realizar una clasificación del corpus editorial caballeresco, José Manuel Lucía Megías define las cinco crónicas escritas por Feliciano de Silva como representativas de la tendencia experimental, una tendencia que desborda los límites del paradigma amadisiano con el objetivo de lograr «la diversión y el entretenimiento» («Libros de caballerías castellanos: textos y contextos», en Edad de Oro, 21 (2002), pp. 9-60, pp. 29-30).

${ }^{13}$ Por encima de la diversidad argumental que preside el variopinto universo narrativo de las obras caballerescas de Silva, la oposición temática entre el deseo de consumar la pasión amorosa, surgida como una fuerza arrolladora, y las obligaciones derivadas de la honra, entendida como un imperativo social y personal que condiciona determinadas decisiones, afecta la trayectoria biográfica de la pareja protagonista, compuesta por Florisel de Niquea y la infanta Elena, que viene a ser, en sus inicios, una nueva versión de la legendaria historia de Paris y Elena. Sobre las reminiscencias de la materia troyana en las obras de Silva, nos remitimos a lo dicho por Emilio J. Sales Dasí en «La huella troyana en las continuaciones del Amadís de Gaula», en Troianalexandrina, 6 (2006), pp. 9-32.
} 
La primera irrupción de Sidonia en el mundo ficcional inventado por Silva es quizá la más interesante, al sorprender a los lectores y también a los propios personajes por la singularidad de unos actos que chocan con su horizonte de expectativas habitual. El episodio que pasamos a comentar se contextualiza en un marco discursivo regido por unos esquemas tópicos, trillados hasta la saciedad en los textos caballerescos. El emperador Amadís de Grecia ha quedado hechizado en la Aventura de la duquesa Armida (2. ${ }^{\text {a }}$ xxxvII). Al no regresar a Constantinopla, son varios los caballeros que emprenden una queste, entre ellos su hijo Florisel de Niquea y su amigo Falanges de Astra. Si la suya es una demanda que se rige por el puro azar, éste pasa a personificarse mediante una de las frecuentes tempestades marítimas que conducen al viajero hasta un lugar donde le aguarda una aventura impensada. De la que Florisel y Falanges son testigos inmediatamente se deduce que va a caracterizarse por su alteridad, en este caso más por los usos de los habitantes de la isla que por los atributos geográficos de la misma. Los caballeros descienden de la embarcación que los ha guiado hasta allí y se adentran por una senda estrecha. Muy pronto quedará su mirada extasiada por los sucesos que acaecen a esa hora en las proximidades de un templo:

en fin de una pieça que assí fueron cabe un gran templo se hallaron, donde dos trechos de ballesta d'él una hermosa ciudad estava; de la cual hazia el templo vieron salir gran número de cavalleros y donzellas con son de diversos menestriles que en torno de un carro triunfal que seis unicornios traían venían; el cual de más de mil cavalleros de resplandecientes armas venía rodeado, los cuales con cochillas, de más de una braça en largo y un paño de ancho, muy limpias, trabadas con ambas manos tenían. Que como más cerca llegassen, vieron el carro que todo era labrado de muy blanco y hermoso marfil, con grandes follajes relevados de oro y azul por él labrados, con las sillas e guarniciones del de los unicornios de fino oro. El carro venía en lo alto obrado de cuatro arcos triunfales de lo mismo qu'el carro, y en ellos venían pasad[a]s de doze cabeças de cavalleros en oro engastadas; y en el medio, más alta una que todas, la cual venía con sobreseñales con las armas reales de los príncipes de Clarencia. Debaxo los arcos venía una tan hermosa donzella como podía ser, vestida de una ropa de terciopelo azul golpeada sobre fina tela de oro, e los golpes tomados con estampas de manojos de flechas, atadas con gruessos torçales de oro e azul. La ropa era muy larga y ceñida, y las mangas de la espalda estrechas, e ívanse encendiendo hasta ser tan anchas de las bocas que al suelo llegavan y, la donzella puesta en pie, todas de infinitos plieg[u] es; sus cabellos tan hermosos, que parescían como fino oro, llevava esparzidos y sobre ellos una corona de forma de reina con infinita pedrería. El braço izquierdo llevava sacado por un golpe que en lo alto de la manga se hazía, y 
de una muga muy justa tela de finas perlas y pedrerías que hasta la moñeca de la mano descendía, en la cual un arco como de fino oro llevava y en la $<$ s $>$ otra $<\mathrm{S}>$ tres cumplidas saetas. A los lados d'ella venían otras dos donzellas en pie, ricamente guarnidas y con arcos y saetas de la misma suerte. En lo baxo y delantero del carro venían tres cavalleros en pie, vestidos de ropas de tela de oro, sembrados de llamas de fuego, en ellas bordadas con gruessas cadenas de oro a las gargantas con que a ciertas argollas del carro venían trabados, y de sí las manos con gruessas cuerdas de seda atadas ante sus pechos. Y assí de tal suerte fueron hasta poner el carro a la puerta del templo, donde la reina que en el carro venía fue d'él abaxada y llevada delante los cavalleros atados de la suerte que los avía traído, llevándole la falda, que muy cumplida era, dos muy hermosas donzellas ricamente guarnidas; poniéndose los cavalleros de las cochillas a los lados en dos órdenes, ella prometió entrar en el gran templo $\left(2 .^{\mathrm{a}}, \mathrm{xxxix}\right)^{14}$.

Aquello que contemplan los ojos de los caballeros se perfila desde un primer instante como un espectáculo que se distingue por la excelencia de cada uno de sus elementos constitutivos. Para empezar, una procesión multitudinaria que rodea un carro triunfal del que tiran seis unicornios. Si la realidad histórica del XVI, y también la del XVII, documenta la celebración de representaciones festivas, de entradas triunfales en grandes ciudades, a causa de determinados acontecimientos públicos ${ }^{15}$, los prolegómenos del episodio literario podrían convertirse en ejemplo de la vinculación que se estableció entre la ficción y la realidad a través de ceremonias de carácter parateatral como ésta. Una condición que discurre de manera visual y efectista a través de la inestimable riqueza con que está adornado el carro y que se reproduce en las suntuosas indumentarias de los personajes que se encaraman sobre él y cuya ubicación bajo los arcos triunfales actúa como un procedimiento para señalar su correspondiente importancia dentro de esta especie de retablo.

Pero ésta sólo es la cara más amable e idealizada de la descriptio del artilugio procesional y de los vestidos de sus ocupantes, aspecto en el que, por

\footnotetext{
${ }^{14}$ Citamos a partir de la edición de 1532, Valladolid, Nicolás Tierri. Este episodio aparece reproducido en su integridad en mi Antología del ciclo de «Amadís de Gaula», Alcalá de Henares, Centro de Estudios Cervantinos, 2006, pp. 265-271.

${ }^{15}$ Sobre este particular son de gran interés las referencias histórico-literarias aportadas por Teresa Ferrer en Nobleza y espectáculo teatral (1535-1622), València, UNED, Univ. de Sevilla y Univ. de València; Alberto del Río Nogueras, «Fiesta y contexto urbano en época de los Austrias, con algunos ejemplos aragoneses», en La fiesta cortesana en la época de los Austrias, coord. por Bernardo José García García y María Luisa Lobato, 2003, pp. 193-209, y José Manuel Lucía Megías, «Los libros de caballerías en las primeras manifestaciones populares del Quijote», en De la literatura caballeresca al «Quijote», coord. de Juan Manuel Cacho Blecua, Zaragoza, Prensas Universitarias de Zaragoza, 2007, pp. 319-345.
} 
otra parte, suele recrearse en numerosas ocasiones Feliciano de Silva hasta el punto que contribuye a plasmar un universo narrativo propio, sofisticado en esencia, y convertirá al autor en modelo al que recurrir cuando otros literatos se animen a incorporar en sus historias minuciosas descripciones de la moda femenina ${ }^{16}$. Junto a los retazos suntuosos, aparecen otros elementos que no deben pasar desapercibidos y que vienen a contrastar con lo dicho en un doble sentido. Por una parte, la presencia de los unicornios podría entenderse como concesión a una estética donde impera a sus anchas la maravilla. Sin embargo, en este episodio en concreto su papel no tiene porqué ser simplemente arbitrario y gratuito. Más aún, el autor puede estar atribuyendo una funcionalidad simbólica tanto a los unicornios como al color blanco del carro triunfal, ya que ambos motivos trascienden como figuraciones de la virginidad y la pureza femenina. Por otra parte, no se olvide, la mención de las más de doce cabezas que van engastadas en oro en el carro y de los tres caballeros cuyas gargantas van atadas con cadenas de oro transmite al discurso un gesto ciertamente oscuro y enigmático: ¿quiénes son estos prisioneros y por qué son conducidos dentro del templo? ¿Deberemos suponer que han cometido algún desaguisado y tienen que lavar sus culpas en un recinto sagrado?

Si seguimos confiando en la perspectiva de los caballeros Florisel y Falanges, participaremos con ellos de su misma incredulidad ante los sucesos de los que son testigos y que pronto van a cobrar un rumbo imprevisto. Tanto por los hechos que se nos relatarán como por la atmósfera que planea sobre la aventura, un ambiente donde el lujo no puede sustraerse a los embates de lo alegórico-sentimental y donde Silva dará buena cuenta de su afición hacia la retórica alambicada cada vez que sus criaturas quieren exteriorizar sus afectos amorosos o sus preocupaciones más íntimas:

Los dos príncipes que mirando cosa tan estraña estavan no sabían qué cosa aquella fuesse, y acordaron de hasta ser fenecido el oficio mirar todo lo que en él passava. Y apeándose de sus cavallos, los yelmos puestos, llegan hasta que en el gran templo hallaron un trono de veinte gradas en alto cubiertas de paños de oro; en el cual un altar estava y encima d'él la diosa Venus y el dios Cupido, dios de los amores, como los pintan los antiguos, todos de

${ }^{16} \mathrm{Si}$ M. ${ }^{\mathrm{a}}$ Carmen Marín Pina ha profundizado en la relación existente entre los retratos femeninos del Palmerín de Inglaterra y la conexión de su autor Francisco de Moraes con los usos cortesanos de su época, recogidos en las relaciones de fiestas (véase «Palmerín de Inglaterra se lleva la palma: a propósito del juicio cervantino», en De la literatura caballeresca al «Quijote», coord. de Juan Manuel Cacho Blecua, Zaragoza, Prensas Universitarias de Zaragoza, 2007, pp. 361-381, espec. las pp. 375-376), dicho aspecto sigue siendo motivo de estudio pendiente en otros relatos del corpus editorial caballeresco. Un cotejo minucioso entre los usos de la época y su hipotética traslación literaria serviría para definir con mayor exactitud la interrelación entre ficción y contexto histórico. 
muchas piedras y perlas sobre fino oro obrados; y en torno del altar muchos candeleros de plata con gruessas hachas en ellos; y todo toldado el templo de rica tapicería. Que, como allí llegasse la reina y las dos donzellas hermosas que con ella con los arcos ivan a los lados una grada sola por subir del trono, pararon los tres cavalleros de las ropas de las llamas. Arrimados al altar los ponen, desnudándolos los lados siniestros; que, como assí estuviessen, todo el regozijo cessó, y la reina quitándole de la cabeça una de sus donzellas la corona, assí comiença a hablar alta la boz que la oían todos:

- ¡Muy excelentes y soberanos dios[e]s Cupido y Venus!, si la fuerça de la fuerça de la vuestra en la de mi hermosura quesistes poner con más que soberana gloria, el presente sacrificio por la de mi grandeza e honestidad a vuestro divinal y forçoso poder se ofrece, porque junto con la grandeza de mi hermosura la razón del conocimiento de la de mi real estado se devía, donde ni el pago de la gloria de tu atrevimiento al presente se te puede negar, ni yo dexar de quebrantar aquella piedad de que naturalmente las mugeres son deudoras, exceto en esto que menos la deven para sacalla a la que más a sus honras y limpiezas son deudoras que a satisfazer a los desseos de la bondad. Por donde, para que aquella cruel flecha que la fuerça de mi hermosura pudo assí al presente tu coraçón llagar, hasta poner en el atrevimiento de mi presencia la fuerça de su mortal herida, pidiendo el remedio que sólo de mi mal no hallar pensavas, no puedo dexar de ponerte la gloria que sólo de mis manos merescías por parte de tus tan gloriosos pensamientos, de los cuales sólo el castigo y pago no se permite, si de mi soberana grandeza no, para satisfazer a ella y a la fuerça que como reina y señora a mis sagradas leyes quise poner. Por la cual rescibe de mis manos la gloriosa llaga para melezina de aquella que de mi hermosura r[e]scebiste para poner al cuerpo y coraçón tuyo en descanso, y el ánima en los arrebatados cielos con la gloria que por virtud de tales pensamientos se le deve. Por donde, para gozar de tal gloria, el ánima dexe el aver poco sosiego y ella vaya a gozar lo que por él en esta vida pudo perder para con doblada gloria lo poder ganar.

Como puede observarse, el desarrollo de la anécdota apunta en una vía donde lo estrictamente caballeresco deja su lugar a unos contenidos que delatan la familiaridad del autor con la ficción sentimental. Si Tobias Brandenberger ya había aludido al parentesco de Silva con dicha tradición literaria a propósito de sendos episodios del Amadís de Grecia (1530) y de la Tercera parte del Florisel de Niquea (1535) ${ }^{17}$, ahora nos hallamos en un ámbito muy próximo, que goza de gran predicamento en las dos primeras partes del Florisel. Bastará recordar que en la 1. a, LIV, de este mismo libro el mismo príncipe Falanges de Astra tributa un culto amoroso a su querida Alastraxerea en un

${ }^{17}$ «Libros de caballerías y ...», art. cit. 
templo dedicado en su honor en la isla de $\operatorname{Colcos}^{18}$. En uno y otro caso, los personajes se inclinan por una devoción herética del ser amado o por su sumisión a los dioses clásicos, prescindiendo por completo de cualquier referencia al Dios de los cristianos. Y es que ambas situaciones se pliegan a las exigencias de un código de conducta que se entiende como reedición sublimada de las doctrinas del amor cortesano, pasadas por el tamiz de la ficción sentimental y reelaboradas con la intensidad hiperbólica que impone Feliciano de Silva a cada uno de los motivos temáticos que maneja. En esta esfera de realidad se inscriben las prácticas de esa reina, cuya identidad todavía no se nos desvela, al entrar en un recinto dedicado a Venus y Cupido.

Feliciano de Silva, que en otras ocasiones se ha mostrado como consumado continuador y recreador de la materia amadisiana, pero que también deja patente en otros lugares su habilidad para incorporar argumentos procedentes de la célebre tragicomedia de Fernando de Rojas a su universo caballeresco ${ }^{19}$, que también, como apuntábamos más arriba, maneja la tradición clásico-troyana, se acoge ahora a los registros de la narrativa sentimental, procediendo a una divinización total del Amor, una fuerza arrolladora y todopoderosa que adquiere una entidad autosuficiente y de la cual dependen los gestos de aquellos y aquellas que creen en su supremacía. Por entender que esa representación personificada del Amor, cuya forma material y explícita son las imágenes de Venus y Cupido, instaura sus normas, esa reina principal, que se dirige a ellos como en una oración, pasa a argumentar los motivos de su visita al templo, haciendo uso de una serie de términos conceptuosos, tales como «honra, medicina, hermosura, gloria, ...», que dan buena cuenta de sus creencias y, a la postre, justificarán su actuación posterior.

A diferencia de las dueñas bravas y vengativas de las que se ha hecho mención previamente, la problemática que parece involucrar a esta reina no se origina en una pérdida personal ni deriva de un daño indeterminado, ni siquiera suscitará el recurso a artificios mágicos para agredir a un tercero. La dialéctica que la envuelve se ubica en un terreno abstracto, jalonado por las típicas reacciones y expresiones antitéticas que genera el Amor. Éste y no otro es el responsable primero de los sucesos que tendrán lugar en el discurso.

\footnotetext{
${ }^{18}$ Recogemos este episodio en la citada Antología del ciclo de «Amadís de Gaula», pp. 256-258.

${ }^{19}$ Aparte de proseguir la historia de la famosa alcahueta, resucitándola literariamente en su Segunda comedia de Celestina, el regidor de Ciudad Rodrigo aprovecha sus aficiones lectoras para enriquecer sus crónicas caballerescas, tal y como se subraya en Emilio J. Sales Dasí, «Ecos celestinescos en el Lisuarte de Grecia de Feliciano de Silva», en Tirant, 3 (2000) [http://parnaseo.uv.es/tirant], y «Feliciano de Silva, aventajado "continuador" de Amadises y Celestinas», La Celestina, V Centenario (1499-1999), ed. cuidada por F.B. Pedraza, R. González y G. Gómez, Cuenca, Univ. de Castilla-La Mancha, 2001, pp. 403-414.
} 
De modo más gráfico, la hermosura de la reina ha abierto esa herida que altera el juicio de los humanos y también el de ese caballero que es llevado hasta el altar. Aunque el enamorado no sea responsable del nacimiento de una pasión que se define como involuntaria, las obligaciones de la dama, el mantenimiento de su honestidad, más aún teniendo en cuenta "su real estado", exigen de una respuesta práctica para castigar el supuesto "atrevimiento" del caballero. Una respuesta que le otorgará al enamorado, a la vez, descanso para su atribulado cuerpo y su corazón, pero también la gloria por la magnitud de unos sentimientos que ennoblecen su espíritu.

Atendiendo a las razones que expone la reina ante sus dioses, los eventos que se suceden acto seguido, aun en su crueldad, no deben ser interpretados como pecado ni como atroces ejecuciones, pues se basan en una lógica argumental de la que los caballeros testigos y los mismos lectores tendrán conocimiento un poco más tarde. De momento, el altar del templo se tiñe de sangre a partir de tres sacrificios humanos que le confieren a la escena un dramatismo excepcional, si bien, repetimos, justificado por la idiosincrasia de los cultos religiosos ofrecidos como un rito ceremonial al Amor:

Y como esto dixo, una flecha que en el arco puesta tenía al cavallero que en medio estava la lançó por derecho de coraçón, de suerte que, atravesado con ella, luego ant'el altar muerto cae. Y de sí las donzellas luego dixeron:

- Por la fuerça de las leyes de la reina, nuestra soberana señora, [sea] rescebida aquella de nuestra limpieza e honestidad.

Y luego con sus arcos, de la suerte de la reina, a los otros dos cavalleros hieren. Que, como huvieron caído, luego en un punto los coraçones les fueron sacados; e, puestos en una gran custodia de oro, con muchos olores sobre el altar fueron quemados; $y$ en tanto que se acavan de quemar, a la reina y a las otras dos donzellas dieron sendas harpas, con las cuales y sus bozes, diziendo cantares con que los coraçones aquellos dioses ofrecían y a los cielos las ánimas encomendavan, estuvieron hasta que del todo fueron quemados. E como fueron acabados de quemar, las cabeças de los cuerpos fueron tajadas y en sus engastes, que aparejados estavan, la del que la reina avía muerto fue como las otras al carro llevada, y las de las donzellas fueron ant'el altar con otras muchas colgadas. Y luego la reina fue cubierta con paños de duelo, y sus donzellas con ella, e tornadas en el carro de la suerte que avían venido, dexando los príncipes espantados de la crueldad de tal aventura e muy desseossos de saber el secreto d'ella.

Y en efecto, Florisel y Falanges de Astra no tardan en satisfacer su curiosidad y en salir de su extrañamiento ante aquello que acaban de ver y que les llena de espanto. Un viejo encargado de dar sepultura a los caballeros 
decapitados les hace relación exacta y minuciosa de las razones por las que se realizan esos sacrificios. Las explicaciones de dicho personaje informante permiten reconocer la existencia de unas constantes en la narrativa de $\mathrm{Fe}$ liciano de Silva, que hermanan el rumbo temático de sus textos a partir del Amadís de Grecia. Según sabemos, la "ejecución" comentada es una práctica que ha sido establecida por la reina Sidonia, señora de la ínsula de Guindaya, también conocida como la de los Sacrificios de Amor en las Leyes de Sidonia. Desde hace un año, la propia reina promulgó unas normas, las Glorias de Sidonia, a las que nadie podría sustraerse. De acuerdo con ellas, aquellos o aquellas que estuviesen interesados en amar a otra persona jamás podrían manifestar su pasión a escondidas, sino hacer una petición pública de esponsales, de forma que quien era pretendido, o respondía favorablemente o terminaría sus días decapitado. Esta normativa, desarrollada más ampliamente a través de retóricas puntualizaciones, responde a un deseo de la reina por mantener limpia su honra y la de todas sus mujeres. Y viene a ratificar la enemiga de Sidonia hacia la ligereza con que algunos caballeros de la misma estirpe del rey Amadís jugaron con los sentimientos y reputación de otras señoras principales:

- Mis buenos señores, -dixo el home anciano-, no vos maravillés, que lo que la reina hizo, allende de lo que avés oído, hazer estas leyes fue por vengarse de todos los cavalleros, porque supo de cómo un príncipe falsó el amor por él pedido a una hija del rey de Francia llamada Lucela, y para exemplo y castigo de tal deslealtad la reina hizo las leyes que avés oído e no se ha querido casar hasta casarse conforme a sus leyes e a su contentamiento, paresciéndole que, según su limpieza e hermosura, ninguno la merescer si no fuesse el excelente príncipe don Falanges d'Astra, del cual por las nuevas de sus virtudes y hermosura dessea la reina, mi señora, casar con él.

Frente a la deslealtad amorosa ${ }^{20}$, la reina de Guindaya habilita en sus territorios una legislación exagerada, al lado de la cual parece ridícula la reacción

\footnotetext{
${ }^{20}$ Muchos de los personajes de Silva adquieren un sello distintivo a partir de su postura ante el amor y, sobre todo, hacia la fidelidad amorosa. Pese a resultar demasiado generalizadora la afirmación, puede concluirse que existe un progresivo distanciamiento de las pautas sentimentales encarnadas por los protagonistas del Amadís de Gaula de Garci Rodríguez de Montalvo. Ya no se trata simplemente de que cualquier miembro del linaje amadisiano tenga amoríos y relaciones carnales con una o más personas del otro sexo, sino de la continua oposición, muchas veces con voluntad humorística, de perspectivas antagónicas que igual tienden a valorar como excelencia suprema la lealtad como la ponen en entredicho desde actitudes en las que campea la lascivia. Se comentan varios de estos comportamientos y perspectivas en Emilio J. Sales Dasí, «Las Sergas de Esplandián y las continuaciones del Amadís (Florisandos y Rogeles)», en Voz y Letra (Revista de Literatura), 7/1 (1996), pp. 131-156 y «El humor en la narrativa de Feliciano de Silva: en el camino hacia Cervantes», en Literatura: Teoría, Historia y Crítica, 7 (2005), pp. 115-157.
} 
de Oriana al suponer que su querido Amadís de Gaula, en la obra homónima, la engañaba con Briolanja. Aquí se implantan unas pautas con valor coercitivo que, de ser ignoradas, pueden dar pie a funestas y sangrientas consecuencias. Por un instante, el lector igual se siente inclinado a pensar que el narrador toma partido por la perspectiva femenina. Pero eso es mucho decir. Lo que sí es cierto, es que tales normas se relacionan en cierto modo con el catálogo amoroso que se plantea en el Sueño alegórico que aparece entre la Primera y la Segunda parte del Amadís de Grecia. En él, el mismo Silva se encuentra con Juan Rodríguez del Padrón y tiene que demostrar ante el dios Amor que ha respetado sus Mandamientos, para acreditarse como leal amador. La asunción de los dogmas propagados por la ficción sentimental se manifiesta ahora de una manera más gráfica en las costumbres que se siguen en la ínsula de Guindaya. Así como también la preocupación exacerbada de las féminas por su honra repuntaba en otros episodios de la narrativa de Silva (traigamos a colación aquel donde la infanta Mirabela se suicida después de que el repulsivo Monstruofurón asesinara a su padre y la raptara contra su voluntad [Amadis de Grecia, 2. ${ }^{\mathrm{a}}$, CXVII]; o aquel en el que la infanta Silvia es arrojada a las tierras de Niquea y, después de ser capturada por unos caballeros, logra escapar y se plantea la posibilidad del suicidio para mantener intacta su honra y su castidad, acto que Alastraxerea logra impedir [Primera parte del Florisel, xxI]). Sin embargo, incluso el tono solemne que envuelve la presentación de estas actitudes no puede enmascarar que las convicciones defendidas por dichas mujeres son sólo una opción personal dentro una mundo abigarrado y multiforme. Nunca serán las alternativas únicas, ni las más sugestivas. Forman parte de un conjunto discursivo en el que se han pluralizado y diversificado las perspectivas ante el sentimiento amoroso.

Por todo ello, nadie deberá sorprenderse de que las preocupaciones que han llevado a Sidonia a establecer en sus territorios unas leyes que no son de índole divina, ni han surgido del común acuerdo, comporten en su mismo seno una vulnerabilidad que va a comprometer, a continuación, la propia existencia biográfica de la reina. La mujer que ha rematado con su flecha a varios pretendientes para hacer justicia, o lo que ella denomina como tal, con el sexo masculino, que confía en unos dioses a los que ofrece sus sacrificios, va a ser víctima de sus intenciones y del entramado legal que ella ha promulgado para evitar la deslealtad en amores y para preservar la honra femenina. Después del remedo de los usos conceptuales y discursivos de la literatura cortesana sentimental, después del dramatismo con que el Amor somete a sus seguidores, Sidonia abandona, a su pesar, el lugar superior que ostenta en la 
fábula para caer a los pies de un engaño. Ella será una criatura atrapada en sus propias redes, según plasmará el desarrollo posterior del episodio, el mismo que enfatiza la habilidad del autor para superar los moldes temáticos que le han servido como fuente de inspiración para dotar su relato de una atractiva variedad. Paralelamente, el hilo argumental sufre un enrevesamiento manierista del que no cabe excluir sus implicaciones humorísticas.

Habiendo conocido las costumbres que imperan en Guindaya, Florisel de Niquea y Falanges de Astra pretenden regresar a su barca para continuar con su queste. No obstante, su presencia no pasa desapercibida para algunos caballeros de la ínsula, que intentan obligarles a presentarse ante la reina Sidonia. Unos y otros se ensarzan en una lid que interrumpe la misma señora del lugar. Entonces, Sidonia cree reconocer a Falanges, ese atractivo caballero del que sólo tenía referencias de oídas y que ahora adquiere una dimensión corpórea real. Si un día se planteó la posibilidad de contraer matrimonio con un paladín tan virtuoso y reputado, en este momento la reina piensa que le ha llegado la ocasión para cumplir sus intenciones. Se equivoca. Cuando el caballero la mira, rememorando la imagen de su señora Alastraxerea, ella interpreta erróneamente sus sentimientos y reúne a toda su corte en la plaza pública para pedir su mano, sin intuir que va a quedar comprometida por las mismas leyes que han propiciado varias muertes. Delante de su pueblo, Sidonia se dirige a Falanges y le expone sus deseos. Lo que no espera es obtener una respuesta negativa a su demanda. Falanges no puede trasplantar la lealtad que lo obliga a la que considera su diosa Alastraxerea, de modo que prefiere la muerte a la renuncia de su confesada sumisión amorosa. La falta de reciprocidad entre Sidonia y Falanges origina una tensión climática en el relato, propiciada por la existencia de ese código legal que sanciona la pertinencia del derramamiento de sangre en situaciones similares. Sin embargo, Feliciano de Silva quiere dar un desenlace diferente a los hechos, recurriendo para ello a un motivo al que ya había dado entrada en los folios de su Amadís de Grecia. Allí el caballero protagonista tomó los hábitos de doncella sármata para poder acceder hasta su amada Niquea $\left(2 .^{a}\right.$, LXXXVII) y, luego, Florisel adoptó el traje de pastor para aproximarse a Silvia (2. ${ }^{\mathrm{a}}$, CXXXII). Vista la eficacia narrativa del disfraz, aparte de que dicha estrategia poseía un valor teatral que tan del agrado era de Silva, en la Primera parte del Florisel otros personajes hicieron uso de él: por ejemplo, Arlanda se disfrazó con las ropas de pastora de Silvia para disfrutar del contacto carnal con Florisel (cap. XII). Pero si el cambio de hábito puede servir para superar cualquier tipo de barreras, tanto físicas como abstractas, existe otro ardid cuya funcionalidad es idéntica y permite escapar de situaciones comprometidas: en muchos casos 
bastará con adoptar otro nombre u otra identidad (así el parecido entre Florisel y Alastraxerea les servirá a cada uno de ellos para huir de la airada Arlanda en la Primera parte del Florisel de Niquea, XLII y XLIV, respectivamente)

Ésta es la salida que vuelve a calibrar el caballero Florisel para salvar la vida de su amigo Falanges. Puesto que Sidonia lo desconoce, él toma la identidad del príncipe Moraizel de la Trapoboña y le pide a la reina su mano en matrimonio. Hasta aquí todo sería normal si el lector no supiese que Florisel ya está desposado en secreto con Elena, una relación que provocó precisamente en la obra un conflicto armado de grandes dimensiones, en el que, además de las espadas, lidiaban dos conceptos como el Amor y la Honra. Así las cosas, cuando Sidonia acepta la solicitud del falso Moraizel y Falanges consigue escapar a una muerte segura, se está consumando un engaño que transgrede el sentido de esas leyes que rigen en Guindaya. Pese a tratarse de la solución menos cruenta para salir airoso del compromiso, los hechos que se suceden, boda entre Florisel-Moraizel y Sidonia y encuentros carnales entre los esposos, ponen de nuevo en circulación el motivo de la deslealtad en amores. Significativamente, a través de la doble perspectiva impuesta en el relato: la del caballero que parece actuar, a su pesar, para liberar a su amigo y la evidencia de que el propio Florisel-Moraizel goza en su nuevo estado como bígamo, trasciende el guiño cómplice del narrador, que explicita nítidamente la transgresión de cualquier vínculo legal y amoroso:

Y con esto en el lecho fue puesto, donde dexándolos solos con sólo una apartada hacha que en la cuadra quedó don Florisel a la reina de sus braços t[e]nía; la cual considerada d'él la su tan acabada hermosura y disposición, no con tanta libertad del engaño como él pensava, teniendo de tal suerte tan acabada donzella, assí le comiença a dezir:

— ¡O, mi señora!, ¿con qué puedo yo a los dioses soberanos pagar tan gran merced como que con tanta gloria vuestra y mía la de vuestra gran hermosura otorgada me fuesse? Bienaventurada Fortuna, que con tan contraria de tanta ventura me la pudo aparejar y negarla aquel que meresciéndola más que ninguno no se la quiso otorgar para que yo d'ella gozasse.

Y diziéndole esto, la besava muchas vezes teniéndola entre sus braços (2. ${ }^{\mathrm{a}}$, xli).

Transcurrido un tiempo, Florisel y Falanges parten de Guindaya. Mientras tanto, la dama cruel que mataba para mantener intacta su buena reputación queda en cinta. Su embarazo y el posterior nacimiento de la princesa Diana son la prueba evidente de una deslealtad en amores. La de Florisel hacia su esposa Elena y la de Florisel hacia una Sidonia que se siente burlada y despechada. Una mujer que en la Tercera parte del Florisel repartirá retratos de 
su hermosísima hija para ofrecer su mano a aquel caballero que le traiga la cabeza del caballero que burló su honra y dejó al aire la vulnerabilidad de sus leyes ${ }^{21}$. Al final, tantas muertes, tantos sacrificios humanos, no sirvieron para evitar lo inevitable.

Entre divinizaciones de la pasión amorosa, de equívocos y transgresiones, la peripecia biográfica protagonizada por Sidonia se aparta de los esquemas narrativos que los libros de caballerías utilizaron para plasmar el tipo actancial de las dueñas crueles, bravas y vengativas. La brutalidad con que Sidonia infringe un daño a los caballeros no se define por su primitivismo, ni es síntoma de una barbarie diabólica o asocial. Muy al contrario, es la excusa elegida por Feliciano de Silva para hurgar en los entresijos de la artificiosidad de la retórica sentimental, llevada hasta sus extremos más sangrientos. A partir de ella el autor demuestra su capacidad creativa para remontarse sobre distintos modelos literarios, al tiempo que revela su habilidad para exprimir las potencialidades argumentales a un motivo concreto.

$Y$ es que el papel que el autor le tiene reservado a la reina Sidonia no es ni meramente secundario, ni se consuma en una aventura cerrada y autónoma. Muy al contrario, las consecuencias de su encuentro marital con Florisel, unión que, recuérdese, era una manera de escapar a las obligaciones impuestas por las Glorias de Sidonia, se prolongan más allá de los límites materiales del décimo libro del Amadis. La historia personal y familiar de la reina engarza con la siguiente secuela literaria de Silva y se convierte en uno de los hilos argumentales de la misma. Para ello, le brinda al autor un escenario geográfico e involucra a unos nuevos personajes que comparten protagonismo con los antiguos. La historia ficticia evoluciona al ritmo de la sucesión generacional del estamento caballeresco, estableciéndose una quimérica continuidad donde alternan las luces y las sombras.

La crueldad de Sidonia no cierra caminos, sino que abre otros igualmente interesantes para el público lector u oyente de la Tercera parte del Florisel de Niquea. Su reino de Guindaya se transforma en el horizonte hacia donde

\footnotetext{
${ }^{21} \mathrm{La}$ imposibilidad de consumar plenamente las expectativas amorosas hermana la trayectoria de diversas mujeres que aparecen el los relatos de Silva, féminas que reaccionan de forma semejante y en las que el despecho despierta el ansia de venganza. No es extraño que observemos que los gestos de una de ellas se ofrecen como geminación muy cercana a los de otra dama con las mismas intenciones (la gran familiaridad entre algunos personajes viene a complementar la enorme similitud entre determinadas secuencias narrativas, aspecto que se desarrolla en Emilio J. Sales Dasí, «Feliciano de Silva en el espejo de Feliciano de Silva», en Letras, 50-51 (2004-2005), pp. 272-295). Así, por ejemplo, el afán de Sidonia por castigar la osadía de Florisel se corresponde con la obsesión de la princesa Arlanda por infringir un daño al mismo caballero, puesto que no puede conseguir su amor y le está huyendo constantemente. Es por eso que, en la Primera parte del Florisel (XLVII), Arlanda enviará a la amazona Alastraxerea a la Torre del Universo para que le corte la cabeza al guardián del recinto fadado que no es otro que Florisel.
} 
dirige sus pasos Agesilao, curiosamente hijo de Falanges de Astra y enamorado de Diana a partir de su retrato ${ }^{22}$. Mientras la hermosa princesa vive recluida en una torre ${ }^{23}$, obrada por el mago Cinistides, y su enamorado trata de traspasar sus barreras convertido en otra doncella sármata con el nombre de Daraida (reiterando la estratagema del disfraz de Amadís de Grecia-Nereida), Sidonia conserva intacto su deseo de desquitarse de Florisel, pero ya no es la dama altiva que sacrificaba a quienes incumplían sus leyes. Su odio no puede ocultar el amor que sigue sintiendo hacia su falso esposo. De algún modo, la fuerza del amor la ha amansado por dentro, a pesar de que externamente quiera aparentar una fiereza extrema. La prueba más evidente de su debate interno se produce cuando, finalmente, Daraida le trae hasta Guindaya a Florisel. Para Agesilao-Daraida el cumplimiento de esta tarea le puede permitir obtener la mano de Diana, pero, como le pidió a la reina que le otorgase un don, exige a Sidonia que sea ella misma la que corte la cabeza del caballero mientras duerme. La mujer cruel y despechada cae desde las alturas de su orgulloso pedestal y vacila. Duda entre satisfacer a su palabra y limpiar su honra, o respetar los dictados de su corazón. La dialéctica amor-honra se reproduce gráficamente mediante su dramática reflexión retórica:

La reina, en cuanto esto dezía, no partía los ojos de don Florisel, ni de derramar lágrimas cessava; y tomada la espada de mano de Daraida, se llegó al lecho, pensando todas que la cabeça le quisiesse tajar; y llegada tales palabras dixo:

- ¡Ó, amor y obligación de grandeza, qué medio tengo en las manos para concertarlo en tan grandes estremos! ¡Ay, honra, y con cuánta obligación me obligas a satisfazer mi injuria! ¡Ay, amor, y con cuánta fuerça me fuerças a contradezir mi obligación! ¡Ó, Moraizel, retrato de don Florisel y más verdadera alma de Sidonia, con cuánto descuido en mi cuidado te veo! ¡Ay de mí, y qué haré con tan grandes estremos como tengo puestos delante! (CXXXII, 398) 24 .

\footnotetext{
${ }^{22}$ La mayor importancia que se le concede a los espacios habitados o regidos por mujeres ya se evidencia en el Amadís de Grecia y alcanzará su punto más excepcional en la Cuarta parte del Florisel de Niquea (1551), cuando el autor nos conduzca hasta el Valle de Lumberque, escenario donde tiene su corte bucólica la emperatriz Archisidea y los caballeros que allí acuden disfrazados de pastores deben acatar las órdenes y decisiones de una fémina que, como su nombre parlante indica, es más que una diosa.

${ }^{23} \mathrm{El}$ motivo de la reclusión y la crianza de bellas princesas en lugares a los que no pueden acceder los caballeros, y por extensión los hombres, aúna la biografía de las protagonistas de los relatos de Feliciano de Silva, tal y como se analiza en Emilio J. Sales Dasí, «Princesas “desterradas” y caballeros disfrazados. Un acercamiento a la estética literaria de Feliciano de Silva», en Revista de Literatura Medieval, 15/2 (2003), pp. 85-106.

${ }^{24}$ Citamos por la edición de Javier Martín Lalanda, Alcalá de Henares, Centro de Estudios Cervantinos, 1999.
} 
Después de tales cavilaciones, la intención de la reina de suicidarse, que impedirá Daraida, pone de manifiesto el triunfo definitivo del amor sobre todas las limitaciones que los humanos quieran interponer en su avance, ya sea bajo la forma de decretos legales o bajo la tozuda resistencia a defender la honra con sacrificios que no logran evitar lo inevitable.

La trayectoria de Sidonia, a vueltas con el amor y la honra, se resuelve como la ejemplificación de un conflicto que trasciende a los personajes de la ficción. Con argumentos extraídos de la tradición sentimental, sometidos a una serie de juegos actanciales, a un ir de aquí allá complicando el hilo de la trama y generando situaciones equívocas que dan entrada a la risa, Feliciano de Silva hace de la crueldad femenina un motivo de más empaque temático y estructural que cuando consistía en la mera introducción de nuevos adversarios con los que tenía que bregar el héroe. Ahora no se concibe la crueldad como un obstáculo que impulsa al caballero a mostrar su ardimiento para eliminar conductas asociales. Al vincularla de lleno con el amor y sus efectos, el autor dramatiza, con registros plurales, creando a veces momentos de máxima tensión y en otras ocasiones jovialmente distensivos, un sentimiento que podía complacer los gustos más y menos cortesanos de lectores que podían tener expectativas diferentes. Así se cumplía con uno de los imperativos característicos de los libros de caballerías: el entretenimiento.

Recibido: 10/03/2011

Aceptado: 1/05/2011 


\section{$\cos$}

RESUMEN: Además de la figura de la mujer vengativa, también es posible encontrar en los libros de caballerías la presencia de la dama que actúa con extremada crueldad para defender su honra. A partir del personaje de Sidonia y las costumbres establecidas en su Ínsula de Guindaya (Florisel de Niquea, I-II), este trabajo reflexiona sobre los experimentos temáticos y narrativos de Feliciano de Silva, que suponen una evolución del paradigma del Amadís de Gaula y una superación de los tópicos amorosos de la narrativa sentimental, mediante la confluencia de elementos efectistas, alegóricos y humorísticos.

ABSTRACT: Apart of the figure of the vindictive woman, is also possible to find in the romance of chivalry the figure of the lady who acts with extreme cruelty to defend her honour. Based on the character of Sidonia and the customs established in his Ínsula de Guindaya (Florisel de Niquea, I-II), this work reflects on the thematic and narrative experiments from Feliciano de Silva, which mean an evolution in Amadís de Gaula's paradigm and a superseding of the love topics from the sentimental narrative, by means of the convergence of dramatic, allegorical and humorous elements.

PaLABRAS CLAVE: Lectura femenina. Florisel de Niquea. Sidonia. Ficción sentimental. Leyes de amo. Efectismo. Humor.

Keywords: Women's Reading. Florisel de Niquea. Sidonia. Sentimental fiction. Laws of love. Efectismo. Humor. 
